\title{
THE DISTRIBUTION OF NYMPHAEA CANDIDA C. PRESL (NYMPHAEACEAE) IN POLAND
}

\author{
MACIEJ WAYDA \\ Institute of Botany, Jagiellonian University \\ Lubicz 46, 31-512 Kraków, Poland
}

(Received: June 14, 1999. Accepted: January 10, 2000)

\begin{abstract}
Nymphaea candida C. Presl is a rare species limited in its distribution to NE Poland. It has often been confused with $N$. alba $\mathrm{L}$., a much more frequent species. It is probably a threatened species.
\end{abstract}

KEY WORDS: Nymphaea candida, N. alba, aquatic plants, border of range, distribution of rare plants, plants protected in Poland.

\section{INTRODUCTION}

Almost one hundred year ago, Abromeit (1898-38) determined that Nymphaea candida C. Presl reached the western border of its range on the Vistula river line in Prussia. This statement was confirmed by other Prussian florists. Müller (1911) recorded only one locality of this species westward from mentioned border, in the Western Pomerania, in the vicinity of Słupsk. (Nevertheless this locality has not been included in the listing given in this paper due to a lack of herbarium evidence).

At the same time, this species was reported from Lower Silesia and from central and southern Poland. Many botanists still believe that Nymphaea candida occurs more frequently than Nymphaea alba. Since plants of both species were frequently misidentified, it was not possible to determine their distribution in Poland, which would allow them to be included in the atlas of the protected plant species (Zając A., Zając M. 1997). Only a few researchers (e.g. Tomaszewicz 1979) considered northern water lily as a rare species. Due to the fact that the preparations for the 'Atlas of the Distribution of the Vascular Plants in Poland' (ATPOL) are ongoing, there is a need to solve the problem of the geographic distribution of $N$. candida in our country. This study is aimed at achieving that goal.

\section{COMMENTS ON THE OVERALL DISTRIBUTION OF N. CANDIDA}

In the famous works of Hulten and Fries (1986) and Meusel et al. (1965), the maps of the general distribution of $N$. candi$d a$ may be found. One may conclude from them that this species represents the Euro-Siberian element. The westernmost localities are on the line of Rhine. A revision of the distribution of this species in Poland requires that the western border of its range is verified. In the eastern part of Germany, $N$. candida occurs only in the mountains (Benkert et al. 1996). It appears that the southern border of its range in Europe also needs to be revised. In the Atlas Florae Eúropaeae (Jalas and Suominen 1989), N. candida is reported from many localities in the Czech Republic (Slavik 1986), which requires verification.

\section{COMMENTS ON TAXONOMY}

The differences among the species of the water lilies were subject of detailed studies (Muntendam et al. 1996). Mistakes in plant identification occurred most frequently when one trait connected with stamen morphology was used, even though is was referred to in the Rośliny Polskie (Szafer et al. 1953). The trait, namely the ratio of the width of the stamen filament to the width of the anther in the innermost stamens, is misleading. According to the Dutch researchers (Muntendam et al. 1996), the average value of the index is 1.3 in $N$. alba and 1.8 in $N$. candida. I have never encountered a specimen of $N$. alba in which the filament of the inner stamen would be narrower than the width of the anther. The traits most useful for the identification of our species of water lilies are given in Table 1.

Fresh specimens are much easier to identify than dry material. The most variable are the colors and the position of the main nerve leafslips. The most constant are the characteristics of the pollen.

Our species of water lilies differ in their ecological preferences. Ahlfvengren (1901) noticed that Nymphaea alba and Nymphaea candida almost never occur together. Indeed, the species prefer water of different chemical profile. Kłosowski and Tomaszewicz (1993) showed that Nymphaea candida prefers mesotrophic and soft water, while Nymphaea alba occurs in more eutrophic water. 
TABLE 1. Traits most useful for the identification of Nymphaea alba and N. candida

Nymphaea alba
Extensions of the main nerve leafslips are divergent (study on fresh
material only!)

At the peak of the flowering, the flower is fully opened (rarely partially opened)

\section{Flower base is rounded}

The stigma is yellow and glossy

The number of carpellary teeth is usually more than 15 , rarely fewer than 15

Pollen grain covered with thick, sparsely distributed papillae
Nymphaea candida

Extensions of the main nerve leafslips are convergent or parallel (study on fresh material only!)

The flower is never fully opened

Flower base is quadrilateral

The stigma is pink to claret (green in young flowers), dull.

The number of carpellary teeth is fewer than 15 .

Pollen grain covered with thin, densely distributed papillae

\section{COMMENTS ON THE DISTRIBUTION IN POLAND}

Nymphaea candida occurs only in the north-eastern part of Poland, as shown in Figure 1. In contrast, $N$. alba is a frequent species in all over Poland (Fig. 2). Even within its range, $N$. candida is a rare species. The fact that most herbarium specimens are old is a cause of concern. This situation may be due to the florists' collecting this species only occassionally or to the disappearing of this species as a result of human activity or water eutrophication. Finding a solution to this problem is important from the point of view of the protection of this species and, potentially, for considering this taxon a vanishing species.

\section{THE LISTING OF THE LOCALITIES OF N. CANDIDA IN POLAND}

This listing includes the data so from revised herbarium specimens and from such literature sources information, the authors of which could well distinguish $N$. alba from $N$. candida. Capital letters indicate $100-\mathrm{km}$ squares in the ATPOL grid system. Numbers denote $10-\mathrm{km}$ quadrats. Abbreviations of the herbarium names follow Mirek (1997).

CB GRID SQUARE: 06 -- Lake Kaliska (Kalkranth 1920): 08 -- Luszkowo (Abromeit et al. 1898-1938), Chrystkowo (Abromeit et al. 1898-1938), Lake Gobrowo (Kalkranth 1920):18 -- Deka lg. Kalkranth 1920 (TRN), 28 -- Twardy Dół (H. Preuss 1900): 32 -- Zielona Chocina (Abromeit et al. 1898-1938), Binduga (Abromeit et al. 1898-1938): 47 -Owcze Błota (Preuss 1900): 69 -- Nowe (Abromeit et al. 1898-1938), 76 -- Cekcyn lg. Hellvig 1883 (TRN), 77 -Stembiska (Abromeit et al. 1898-1938), 78 -- Osie (Abromeit et al. 1898-1938), Brzemiona (Abromeit et al. 1898-1938), between Jastrząb and Lnianowo (Abromeit et al. 1898-1938): 80 -- Wiśniewka (Abromeit et al. 1898-1938): 88 -- Lake Budzyńskie (Abromeit et al. 1898-1938): 91 -- Lake Borówno (Abromeit et al. 1898-1938): 99 -- Chełmno (Abromeit et al. 1898-1938).

CC GRID SQUARE: Prov. Piła: 00 -- Skic (Abromeit et al. 1898-1938): 09 -- Storluz (Abromeit et al. 1898-1938), Wielkie Czyste Lake (Abromeit et al. 1898-1938), Grubno

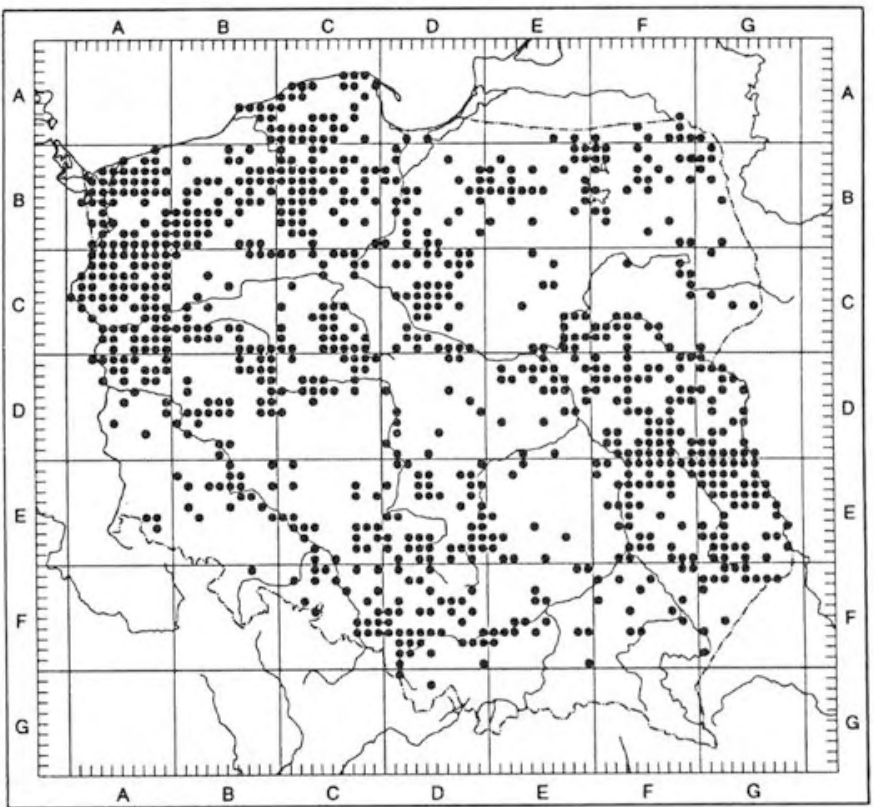


(Abromeit et al. 1898-1938): 87 -- Ostrowite lg. Hohnfalth 1885 (TRN).

DA GRID SQUARE: 80 -- Jasień (Abromeit et al. 18981938): 94 -- Stegna (Abromeit et al. 1898-1938).

DB GRID SQUARE: 37 -- Zielony Mechacz (Abromeit et al. 1898-1938), 42 -- Macki (Abromeit et al. 1898-1938), 43 - Straszewo (Abromeit et al. 1898-1938), 52 -- Kwidzyń (Abromeit et al. 1898-1938), 73 -- Szembruk (Abromeit et al. 1898-1938), Jankowice (Abromeit et al. 1898-1938), 81 -Rudnik (Abromeit et al. 1898-1938), 82 -- Pokrzywno (Abromeit et al. 1898-1938), 84 -- Wielka Tymawa (Abromeit et al. 1898-1938), Lisnowo (Abromeit et al. 1898-1938), 90 -- Podwiesk (Abromeit et al. 1898-1938), 91 -- Pieński Król (Abromeit et al. 1898-1938).

DC GRID SQUARE: 00 -- Kobyły (Abromeit et al. 18981938), Folgowo (Abromeit et al. 1898-1938), 05 -- Lake Niskie Brudno lg. Z. Wójcikowska 1939 (POZ), 06 -- Lake Ostrów lg. Z. Wójcikowska 1939 (POZ), 11 -- Mlewiec (Abromeit et al. 1898-1938), 16 -- Golkówko lg. Alhfevengren 1901 (TRN): 96 -- Drzesno (H. Tomaszewicz 1993 - npbl): 98 -Troszyn 1g. K. Drymer 1898 (WA).

EA GRID SQUARE: 95 -- Wiatrowiec (Abromeit et al. 1898-1938).

EB GRID SQUARE: 05 -- Lusiny (Abromeit et al. 18981938), 12 -- Nowosady (Abromeit et al. 1898-1938), 22 -Lake Żabniczek (Abromeit et al. 1898-1938), Dobre Miasto (Abromeit et al. 1898-1938), 32 -- Lake Stobajno (Abromeit et al. 1898-1938), 40 -- Łabędź (Abromeit et al. 1898-1938), 41 -- Mątki (Abromeit et al. 1898-1938), 42 -- Lake Komin (Abromeit et al. 1898-1938), Lake Zgniłek (Abromeit et al. 1898-1938), 44 -- between Barczew and Lake Szyja (Abromeit et al. 1898-1938), Lake Kierzlińskie (Abromeit et al. 1898-1938), Kiermas (Abromeit et al. 1898-1938), Lake Umląg (Abromeit et al. 1898-1938), 52 -- Olsztyn (Abromeit et al. 1898-1938), 58 -- Lake Kołowinek (Tomaszewicz \& Kłosowski 1993).

FA GRID SQUARE: 78 -- Sudawskie lg. A. Sokołowski 1978 (BIL), 84 -- Galwiecie (Abromeit et al. 1898-1938), 90 - Węgorzewo (Abromeit et al. 1898-1938), 92 -- Czupowo (Abromeit et al. 1898-1938), 99 -- Lake Szlinokiemskie Małe (Tomaszewicz \& Kłosowski 1979),

FB GRID SQUARE: 13 -- Lake Łękuk (Tomaszewicz \& Kłosowski 1993), Lake Róg near Lake Łękuk (H. Tomaszewicz 1996 - npbl), Lake Dubinek (Tomaszewicz 1993), 36 -Kleszczewo (Abromeit et al. 1898-1938), 38 -- Lake Jeziorki (Tomaszewicz \& Kłosowski 1993), 44 -- Lake Liczonka near Ruska Wieś (H. Tomaszewicz 1996 - npbl), 47 -- Przepiórki (Abromeit et al. 1898-1938), Skrzynki (Abromeit et al. 18981938), 56 -- Długosze (Abromeit et al. 1898-1938), 60 -Southern part of Lake Guzianka (Abromeit et al. 1898-1938), 94 -- Pławęż (Abromeit et al. 1898-1938).

GA GRID SQUARE: 90 -- Lake Szlinokiemskie (Tomaszewicz \& Kłosowski 1979), Lake Kompocie (Tomaszewicz \& Kłosowski 1979), Lake Sejwy (Tomaszewicz \& Kłosowski 1979), Lake Boksze (Tomaszewicz \& Kłosowski 1979).

GB GRID SQUARE: 00 -- Lake Gremzdel (Tomaszewicz \& Kłosowski 1979), Lake Szejpiszki (Tomaszewicz \& Kło- sowski 1979), 01 -- Lake Sejwy lg. St. Suchodolska 1938 (KRA), Lake Gaładuś (Tomaszewicz \& Kłosowski 1979), Lake Sztabinki (Tomaszewicz \& Kłosowski 1979), 11 -- Lake Kaczan lg. B. Sudnik 1975 (WA), 22 -- Lake Brożany (Tomaszewicz \& Kłosowski 1979), 31 -- Lake Mikaszówek (Tomaszewicz \& Kłosowski 1979).

GC GRID SQUARE: 24 -- Lake Gorbacz Ig. A. Waszkiewicz 1978 (KRA).

\section{LITERATURE CITED}

ABROMEIT J., NEUHOFF W., STEFFEN H. 1898-1938. Flora von Ost- und Westpreussen. pp. 563. Grafe und Unzer Kommissionsverlang, Königsberg.

AHLFVENGREN F.E. 1904. Die Vegetationsverhältniesse der westpreussischen Moore östlich der Weische, mit besonderer Berücksichtigung der Verändenung der Flora durch Melioration. Schriften der Naturforschenden Gesselschaft in Danzig. 11(1-2): 241-318.

BENKERT D., FUKAREK F., KORSCH H. 1996. Verbreitungsatlas der Farn- und Blütenpflanzen Ostdeutschlands (Meklenburg-Vorpommern, Brandenburg, Berlin, Sachsen-Anhalt, Sachsen, Thüringen). Gustav Fischer, Jena, Stuttgart, Lübeck, Ulm, pp. $55+$ 1988 Verbreitungskarten.

HULTEN E., FRIES M. 1986. Atlas of North European vascular plants. North of the tropic of cancer. vol 1. pp. 498. Koeltz Scientific Books, Köenigstein.

JALAS J., SUOMINEN J. 1989. Atlas Florae Europaeae vol. 8 Nymphaeaceae to Ranunculaceae. Maps 1509-1959, pp. 261.

KALKRATH H. 1920. Die Seen Flora des Kreises Berent. Ber. Westp. Bot-Zool. Ver. 42: 1-6.

MEUSEL H., JÄGER E., WEINERT E. 1965. Vergleichende Chorologie der Zentraleuropäischen Flora. 1 Karten, pp. 1-258. Veb Gustav Fischer Verlag, Jena.

MIREK Z., MUSIAŁ L., WÓJCICKI J. 1997. Polish Herbaria. Polish Botanical Studies. 18: 1-116.

MUNTENDAM J.B., POVELI G.D.E., VAN DER VELDE G. 1996. Morphometric paterns in the Nympaea alba-candida complex. Acta Bot. Neerl. 45 (3): 279-302.

MÜLLER W. 1911. Flora von Pommern. Ed. 3. VIII + 376 pp. Johs Burmeisters Buchhandlung, Stettin.

PREUSS H. 1900. Beitrag zur Flora der Kreises Pr. Stargard. Schrift. Phys.-ökonom. Ges. Königsberg. 42: 64-71.

SLAVIK B. 1986. Phytocartographical syntheses of the ČSR. t.1 pp. 199. [Fytokartografické syntézy ČSR.] Botanický ústav ČSAV. Průhonice.

SZAFER W. PAWŁOWSKI B., KULCZYŃSKI S. 1953. Rośliny Polskie pp. 1019 PWN Warszawa. (in Polish)

TOMASZEWICZ H., KŁOSOWSKI ST. 1979. Rzadkie i interesujące rośliny z Pojezierza Suwalskiego. Fragm. Flor. Geobot. 25(3): 371 375. (in Polish)

TOMASZEWICZ H., KŁOSOWSKI S. 1993. Standortsverhältnisse der Gesellschaften mit Dominanz einzelner Nymphaeaceen in Nordost-Polen. Tuexenia 13: 75-90.

ZAJAC. A., ZAJAC M. (Red.) 1997. Distribution atlas of vascular plants protected in Poland. pp. 100. [Atlas rozmieszczenia roślin chronionych w Polsce.] Kraków. Nakł. Pracowni Chorologii Komputerowej Instytutu Botaniki Uniwersytetu Jagiellońskiego. 
ROZMIESZCZENIE NYMPHAEA CANDIDA C. PRESL (NYMPHAEACEAE) W POLSCE

\section{STRESZCZENIE}

$N$. candida jest przedstawicielem elementu Euro-Syberyjskiego w naszej florze. Roślina ta jest znacznie rzadsza od $N$. alba i występuje tylko w Polsce północno-wschodniej.

Oba gatunki różnią się preferencjami siedliskowymi. $N$. candida występuje w wodach mezotroficznych o niewielkiej twardości, $N$. alba natomiast w wodach bardziej eutroficznych. Grzybienie były i są często mylone przez florystów. Cechy rozróżniające gatunki zawiera tabelka znajdująca się w tekście. Zarówno $N$. alba jak i $N$. candida znajdują się na liście gatunków chronionych w Polsce.

SŁOWA KLUCZOWE: Nymphaea candida, $N$. alba, rośliny wodne, rozmieszczenie rzadkich roślin, granica zasięgu, rośliny chronione w Polsce. 